\title{
Analisis Kesalahan Siswa SMK dalam Menyelesaikan Soal Materi Barisan dan Deret
}

\author{
Asri Septiahani ${ }^{*}$, Melisari², dan Luvy S Zanthy ${ }^{3}$ \\ 1*,2,3Program Studi Pendidikan Matematika, IKIP Siliwangi \\ Jalan Terusan Jend. Sudirman, Baros, Kota Cimahi, Jawa Barat, Indonesia \\ 1*septiahani10@gmail.com
}

Artikel diterima: 30-11-2019, direvisi: 27-05-2020, diterbitkan: 31-05-2020

\begin{abstract}
Abstrak
Penelitian ini memiliki latar belakang yang membahas, bahwa materi Barisan dan Deret pada siswa sangat penting untuk menentukan tentang sebuah daftar bilangan yang mengurut dan memiliki suatu pola atau karakteristik tertentu dalam kehidupan nyata. Tujuan dari penelitian ini adalah mengetahui tingkat kesulitan siswa Sekolah Menengah Kejuruan untuk menyelesaikan soal materi Barisan dan Deret. Subyek yang digunakan adalah 12 orang siswa kelas XII di SMK Kartini Bhakti Mandiri Kabupaten Bandung Barat. Metode yang digunakan dalam penelitian ini adalah deskriptif kualitatif yang hasilnya diperoleh dari pemberian soal sesuai dengan indikator Barisan dan Deret. Analisis dilakukan dengan memberikan tes tertulis berbentuk soal uraian yang berjumlah 5 soal. Penelitian ini merupakan sebuah studi pendahuluan. Hasil analisis data dan pembahasan menjelaskan, bahwa kemampuan siswa pada materi Barisan dan Deret yang masih tergolong rendah. Dari rekapitulasi perhitungan yang telah dilakukan, didapat bahwa persentase kesalahan yang paling banyak dilakukan siswa yakni sekitar $84,5 \%$ pada indikator menyatakan suatu situasi atau masalah sehari-hari tentang Barisan dan Deret ke dalam bentuk model matematika dan menyelesaikannya.

Kata Kunci: Analisis Kesalahan, Barisan dan Deret, Siswa SMK, deskriptif kualitatif.
\end{abstract}

\section{Error Analysis of Vocational High School Students on Sequence and Series}

\begin{abstract}
This research has a background that discusses, that the material Sequence and Series in students are very important to determine a list of numbers that sequence and have a certain pattern or characteristic in real life. The purpose of this study was to determine the level of difficulty of Vocational High School students to solve the Sequence and Series material problems. The subjects used were 12 students of class XII at SMK Kartini Bhakti Mandiri in West Bandung Regency. The method used in this study is a qualitative descriptive which results are obtained from the provision of questions following the Sequence and Series indicators. The analysis was carried out by giving a written test in the form of a description of a total of 5 questions. This research is a preliminary study. The results of the data analysis and discussion explained, that the ability of students in the material Sequence and Series are still relatively low. From the recapitulation of calculations that have been done, it is found that the percentage of errors that most students make is around $84.5 \%$ on the indicator stating a daily situation or problem about Sequences and Series in the form of mathematical models and solving them.
\end{abstract}

Keywords: Error Analysis, Sequence and Series, SMK students, qualitative descriptive. 


\section{Pendahuluan}

Matematika merupakan mata pelajaran yang terdapat pada setiap jenjang sekolah. Fungsi praktisnya adalah mengekspresikan keterkaitan antara kuantitatif dan keruangan, dan fungsi teoritisnya agar memudahkan berfikir (Cartledge, 2005; Firmansyah \& Puspitasari, 2013).

Matematika, juga sangat penting dan berperan dalam hal meningkatkan kemampuan berfikir dan berlogika bagi para siswa, sehingga matematika sebetulnya sangat bermanfaat untuk menjadi alat bantu dan pelayanan ilmu baik teoritis maupun secara praktis yang juga dapat digunakan untuk memecahkan permasalahan sehari-hari sebagai bentuk aplikasi matematika (Tarigan, 2012; Widiawati \& Sofyan, 2013; Afriansyah, 2015).

Hudojo menjabarkan bahwasannya hakikat matematika sangat berhubungan erat dengan ide, serta strukturisasi yang logis. Oleh karena itu, konsep dan manfaat dari pelajaran matematika perlu terinternalisasi kepada siswa/i terutama di SD untuk membangun kemampuan befikir logis, menaganlisa, sistematis, kritis, kreatif serta inovatif (Mulyadi et al., 2015: 370-382).

Kegiatan belajar matematika terkadang mengalami beberapa hambatan (Hidayatilah \& Rahadi, 2013). Salah satu penyebab adanya hambatan hambatan pada proses belajar yaitu siswa masih merasa sulit untuk memahami materi pembelajaran (Sutisna
\& Nanang, 2013; Mayasari \& Afriansyah, 2016) yang berdampak terhadap hasil pembelajaran yang rendah. Penelitian Asy'ari (2015; Ridia \& Afriansyah, 2019) mengemukakan bahwa penulisan rumus seringkali menjadi penyebab kesalahan, karena rumus yang diberikan oleh guru cenderung dihafal oleh siswa, tanpa memahami kontekstualitas rumus tersebut terhadap permasalahan seharihari. Hal itu juga didukung oleh penelitian Yulianingsih \& Dwinata (2018) yang juga menyebutkan kesalahan yang terus menerus terjadi didukung oleh kemampuan penguasaan materi pada siswa yang kurang.

Selain itu, menurut Widyatari (2017) menyebutkan, kesalahan dalam menyelesaikan soal, dijabarkan dalam beberapa kondisi, yaitu kesalahan dalam simbolisasi data, penulisan kembali terkait hal yang ditanyakan, penentuan rumus, serta operasi matematika secara sistematis. Penyebabnya adalah tidak terbiasa dalam menuliskan apa yang ingin diketahui dan yang ingin ditanyakan (Sartika \& Puspitasari, 2013), rumusrumus pada materi barisan dan deret yang belum terlalu dipahami, serta kurangnya memaknai kondisi keseharian melalui latihan soal cerita dan pengecekan jawaban yang seringkali tidak dilakukan.

National Council of Teachers of Mathematics (NCTM) menjelaskan bahwa pemecahan terhadap satu masalah sangatlah variatif dan perlu membangun 
keterhubungan dengan kehidupan seharihari dalam kondisi matematis yang ditimbulkan (National Council Of Teachers of Mathematics, 2000; Lestari \& Madio, 2013). Di sisi lain, model pembelajaran berbasis masalah merupakan salah satu model pembelajaran yang berpotensi memicu semangat setiap siswa untuk terlibat secara aktif dalam proses pembelajaran dan mengembangkan keterampilan berfikir siswa dalam memecahkan masalah (Rusman, 2012; Damayanti \& Afriansyah, 2018).

Materi barisan dan deret merupakan salah satu materi yang penting untuk dipelajari. Kesulitan siswa dalam menyelesaikan soal materi barisan dan deret adalah kesulitan dalam menentukan rumus suku ke-n dari suatu barisan aritmatika dan geometri, memahami konsep suku pertama dari suatu barisan dan memahami maksud dari soal yang diberikan sehingga siswa kesulitan dalam menuliskan apa yang diketahui dan ditanyakan serta menentukan langkah penyelesaian dari soal cerita mengenai materi barisan aritmatika dan geometri (Hardiyanti, 2016).

Newman menjelaskan bahwa kesalahan dalam mengerjakan soal matematika dibedakan menjadi lima tipe kesalahan, yaitu reading error (kesalahan membaca), comprehension error (kesalahan memahami), transformation error (kesalahan pada transformasi), process skills error (kesalahan dalam keterampilan proses), dan endconding error (kesalahan dalam notasi) (Sunardiningsih et al., 2019: 41-45).

Penelitian yang fokus pada diagnosis kesalahan bukanlah suatu hal yang baru (Ekayanti, 2018: 105-116), telah ada beberapa penelitian dengan topik yang serupa, seperti Elbrink dengan penelitiannya tahun 2008, yang menjelaskan bahwa pentingnya menganalisa penyebab dan mengatasi kesalahan matematis sejak awal, karena dapat memberikan masukan kepada guru, sehingga dapat memperbaiki dan mencegah kesalahan tersebut di dalam kelas (Elbrink, 2008). Sedangkan Padmafathy melalui penelitian yang diadakan tahun 2015, menjelaskan bahwa diagnosis terhadap kesulitan-kesulitan siswa perlu dilakukan, melalui diagnosis kesulitan akan diketahui jejak, jenis dan penyebab kesulitan, sehingga guru dapat memberikan jenis bantuan kepada siswa yang relevan berdasarkan diagnosis yang ditemukan (Sunyono; et al., 2015). Riccomini (2005) juga menjelaskan, jika guru abai dan tidak mampu melakukan identifikasi kesulitan secara akurat, akan berdampak terhadap perencanaan dan penyampaian pembelajaran yang tepat dan efektif (Riccomini, 2005). Penelitian tersebut dilakukan dengan menganalisa kesalahan peserta didik berdasarkan jenisjenis kesalahan konsep dan prosedur. Satu inovasi baru yang dilakukan oleh Iman, yaitu dengan melakukan penelitian menggunakan topik yang sama akan tetapi 
penelitian tersebut dilakukan dengan melakukan konfirmasi terhadap Newman Error Analysis.

Adanya analisa terkait proses penyelesaian soal yang masih salah pada materi barisan dan deret, bertujuan untuk menghindari munculnya ketidaktepatan dan ketidakefektifan siswa dalam menyelesaikan soal tersebut, sehingga dapat mencegah timbulnya kesalahan yang sama kedepannya (Rahmawati \& Zanthy, 2019).

Berdasarkan hal tersebut, maka perlu dilakukan upaya untuk menganalisa kesalahan siswa/i dalam menyelesaikan soal matematika, kemudian mengidentifikasi kesulitan belajar matematika, sehingga alternatif pemecahannya dalam menyelesaikan soal materi barisan dan deret dapat ditemukan sedari awal. Diharapkan hasil dari penelitian ini dapat meningkatkan kemampuan para siswa khususnya dalam bidang matematika.

\section{Metode}

Metode deskriptif kualitatif menjadi metode penelitian yang dipilih. Penelitian kualitatif itu sendiri adalah bentuk riset yang membangun narasi deskriptif baik secara tertulis maupun lisan dari responden dan perilaku yang dapat diaobservasi (Lexy \& Moleong, 2019).

Penelitian ini diperoleh dari kajian hasil pekerjaan siswa yang digunakan secara langsung untuk mengetahui jenis kesalahan dalam menyelesaikan soal-soal berdasarkan prosedur Newman. Dengan indikator sebagai berikut:

Tabel 1.

Faktor dan Indikator Penyebab Kesalahan Siswa

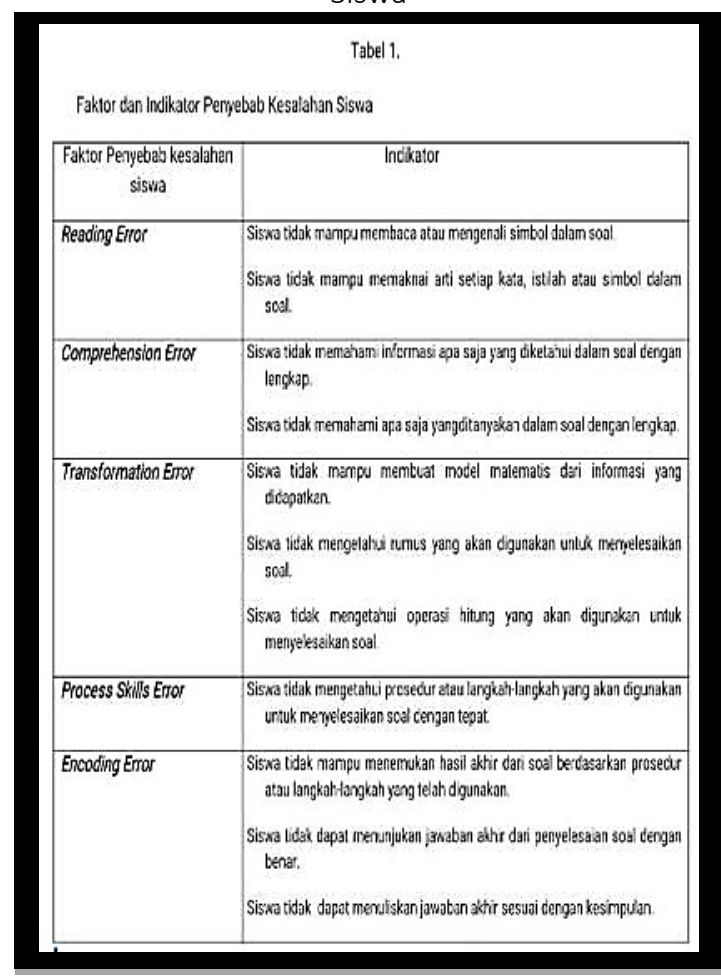

Populasi dalam penelitian ini adalah siswa SMK Kartini Bhakti Mandiri di Kabupaten Bandung Barat, sedangkan sampelnya adalah siswa kelas XII Farmasi yang terdiri dari 12 orang yang memiliki kemampuan kognitif yang heterogen.

Instrumen penelitian yang digunakan dalam penelitian ini yaitu:

a. Soal uraian sebanyak 5 soal mengenai barisan dan deret.

b. Dokumentasi dilakukan tujuanya untuk mencatat dan mengabadikan kegiatan berupa foto pada saat peneliti melakukan observasi kegiatan pembelajaran di kelas, dirancang 
untuk mengumpulkan data-data mengenai kemampuan siswa dalam menyelesaikan soal barisan dan deret.

Soal yang diujikan terdiri dari lima butir soal pertanyaan yaitu:

Soal 1:

Pada tahun 2010 popvlasi sapi di kota A adalah 1600 ekor dan di kota B 500 ekor. Setiap bulan terjadi peningkatan pertumbuhan, 25 ekor di kota A dan 10 ekor di kota $B$. Buatlah model matematkika dai situasi tersebut di atas untuk menghitung populasi sapi dikota B setelah n bulan pada saat populasi sapi di kota A tiga kali populasi di kota B. Soal 2:

Pa Karya mempunyai pinjaman sebesar Rp. 10.000.000,00 yang harus dibayar dengan 5 kali angsuran anuitas dengan bunga pinjaman $12 \%$ per tatun. Susunlah dea buah petantyaan dari informasi tersebul, kemudian selesaikanlàt

Soal 3:

Sesecrang mampunyei sejumlah uang uarng yang akan diambil setiap bulannya yang besamya mengikuti aturan barisan arituatika. Pada bulan perlama diambil Rop. 1.000 .000 , bulan kedua Rp. 925.000 bulan ketiga Rp. 850.000 demikian selerusnya. Jumlah seluruh vang yang telah diambil selama 12 bulan pertama adalah

Gambar 1. Soal Nomor 1 - 3 .

Soal 4 :

Terdapat empat toko pakaian yang menjual jenis barang yang sama. Daftar harga barang dan diskon seperti pada tabel dibawah in

Harga dan Diskon

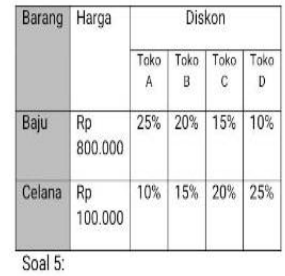

Sebuah gedung pertunjukan mempunyai beberapa kursi.Setelah baris pertama mempunyai 2 kursi lebih banyak dari baris sebelumnya. Perbadingan banyak kursi pada baris ke 9 dan ke 6 adalah 4:3 buatlah model matematika untuk menghitung banyaknya kursi sampai dengan baris ke 9 dan selesaikan!

Gambar 2. Soal Nomor 4 dan 5.

Adapun Indikator soal yang digunakan adalah:

Tabel 2.

Indikator Soal

\begin{tabular}{ccc}
\hline Soal & Indikator & Indikator Barisan \\
No. & $\begin{array}{c}\text { Kemampuan } \\
\text { Komunikasi }\end{array}$ & dan Deret \\
\hline
\end{tabular}

\begin{tabular}{|c|c|c|}
\hline \multicolumn{3}{|c|}{ Matematis } \\
\hline 1 & $\begin{array}{l}\text { Pernyataan } \\
\text { terhadap suatu } \\
\text { situasi keseharian } \\
\text { kedalam bentuk } \\
\text { model matematika } \\
\text { dan } \\
\text { menyelesaikannya }\end{array}$ & $\begin{array}{l}\text { Menyatakan } \\
\text { suatu } \\
\text { permasalahan } \\
\text { barisan dan deret } \\
\text { keseharian } \\
\text { kedalam model } \\
\text { matematika dan } \\
\text { menyelesaikannya }\end{array}$ \\
\hline 2 & $\begin{array}{l}\text { Menyusun } \\
\text { pertanyaan dari } \\
\text { serangkaian } \\
\text { informasi yang } \\
\text { diberikan dan } \\
\text { menjawabnya }\end{array}$ & $\begin{array}{l}\text { Menyusun } \\
\text { pertanyaan } \\
\text { tentang barisan } \\
\text { dan deret dari } \\
\text { serangkaian } \\
\text { informasi yang } \\
\text { diberikan dan } \\
\text { menjawabnya }\end{array}$ \\
\hline $\begin{array}{c}3 \text { dan } \\
5\end{array}$ & $\begin{array}{l}\text { Menyatakan suatu } \\
\text { situasi atau masalah } \\
\text { sehari hari ke dalam } \\
\text { bentuk model } \\
\text { matematika dan } \\
\text { menyelesaikannya. }\end{array}$ & $\begin{array}{l}\text { Menyatakan } \\
\text { suatu situasi atau } \\
\text { masalah sehari } \\
\text { hari tentang } \\
\text { barisan dan } \\
\text { deretke dalam } \\
\text { bentuk model } \\
\text { matematika dan } \\
\text { menyelesaikannya } \\
\text {. }\end{array}$ \\
\hline 4 & $\begin{array}{l}\text { Menyatakan suatu } \\
\text { diagram ke dalam } \\
\text { bentuk soal cerita } \\
\text { dan } \\
\text { menyelesaikannya }\end{array}$ & $\begin{array}{l}\text { Menyatakan } \\
\text { suatu simbol atau } \\
\text { diagram atau } \\
\text { suatu sajian data } \\
\text { lainnya tentang } \\
\text { barisan dan deret } \\
\text { ke dalam bentuk } \\
\text { soal cerita dan } \\
\text { menyelesaikannya }\end{array}$ \\
\hline
\end{tabular}

\section{Hasil dan Pembahasan}

Dari hasil uraian pekerjaan 12 siswa menggunakan prosedur Newman didapatkan hasil yang variatif terhadap jenis kesalahan siswa dalam menjawab soal yang diberikan.

Setelah dilakukan penskoran, nilai tes yang diperoleh siswa beserta persentase ketercapaian yang diperoleh oleh siswa

\section{Mosharafa: Jurnal Pendidikan Matematika}


baik secara individu maupun persentase ketercapaian secara keseluruhan.

Tabel 3.

Perolehan Nilai Tes Siswa

\begin{tabular}{|cccc|}
\hline No Soal & $\begin{array}{c}\text { Rata - } \\
\text { rata }\end{array}$ & \multicolumn{2}{l}{ Jumlah Siswa (\%) } \\
\cline { 3 - 4 } & & $\begin{array}{c}\text { Di atas } \\
\text { rata - } \\
\text { rata }\end{array}$ & $\begin{array}{c}\text { Di bawah } \\
\text { rata - } \\
\text { rata }\end{array}$ \\
\hline 1 & 28 & $43 \%$ & $57 \%$ \\
\hline 2 & 17,5 & $33 \%$ & $67 \%$ \\
\hline 3 & 17,5 & $15,5 \%$ & $84,5 \%$ \\
\hline 4 & 24,1 & $32 \%$ & $68 \%$ \\
\hline 5 & 5 & $8 \%$ & $92 \%$ \\
\hline
\end{tabular}

Berdasarkan data yang ditunjukan pada Tabel 3 menggunakan indikator pembelajaran barisan dan deret, hasil rata-rata pada soal 1 yaitu menyatakan suatu masalah dalam barisan dan deret sehari-hari ke dalam bentuk model dan penyelesaian yang matematis, dengan persentase siswa yang mendapatkan nilai di atas rata- rata adalah $43 \%$ dan 57\% untuk persentase siswa di bawah rata-rata. Hasil rata-rata pada soal 2 yaitu menyusun pertanyaan tentang barisan dan deret dari serangkaian informasi yang diberikan dan menjawabnya adalah 17,5 dengan persentase siswa yang mendapatkan skor di atas rata- rata adalah 33\% dan 67\% untuk persentase siswa di bawah rata-rata. Hasil rata-rata pada soal 3 yaitu menyatakan suatu situasi atau masalah sehari hari tentang barisan dan deret ke dalam bentuk model matematika dan menyelesaikannya adalah 17,5 dengan persentase siswa yang mendapat nilai di atas rata- rata yaitu $15,5 \%$ dan $84,5 \%$ untuk persentase siswa di bawah rata-rata. Hasil rata-rata pada soal 4 yaitu menyatakan suatu simbol atau diagram atau suatu sajian data lainnya tentang barisan dan deret ke dalam bentuk soal cerita dan menyelesaikannya adalah 24,1 dengan persentase siswa yang mendapat nilai diatas rata- rata yaitu 32\% dan $68 \%$ untuk persentase siswa diatas rata-rata. Hasil rata-rata pada soal 5 yaitu menyatakan suatu simbol atau diagram atau suatu sajian data lainnya tentang barisan dan deret ke dalam bentuk soal cerita dan menyelesaikannya adalah 5 dengan persentase siswa yang mendapat penilaian di atas rata-rata yaitu $8 \%$ dan di bawah rata-rata sebesar 92\%.

Analisis kesalahan siswa dalam menjawab soal berdasarkan Newman. Dijelaskan sebagai berikut:

1) Reading Error

Selanjutnya akan dibahas respon dengan mengambil contoh salah satu siswa terhadap soal nomor 1 . Terlihat di gambar 1, siswa tidak mampu membaca atau mengenali simbol dalam soal serta siswa tidak mampu memaknai arti setiap kata, istilah atau simbol dalam soal.

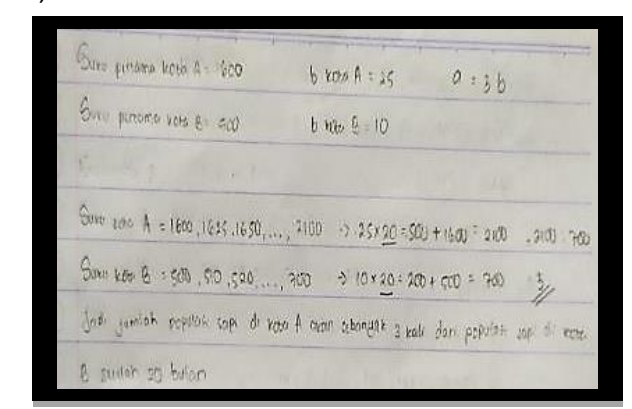

Gambar 3. Respon Siswa terhadap Soal Nomor 1. 


\section{2) Comprehension Error}

Selanjutnya respon salah satu siswa dalam menjawab soal nomor 4 (lihat gambar 2). Terlihat pada gambar tersebut siswa kurang paham tentang informasi apa saja yang diketahui dalam soal dengan lengkap serta siswa tidak memahami apa saja yang ditanyakan dalam soal dengan lengkap. Dalam soal tersebut diperintahkan untuk membuat soal serta menyelesaikannya, namun siswa hanya mengambil salah satu informasi dari tabel tersebut dan tidak secara keseluruhan informasi yang diambil.

Hal ini sejalan dengan penelitian Rahmawati (2019) yang menyatakan kesalahan siswa dalam menjawab soal terjadi karena proses penafsiran informasi yang diberikan ke dalam ungkapan matematika kurang tepat (Delisda \& Sofyan, 2014; Rahmawati \& Zanthy, 2019)

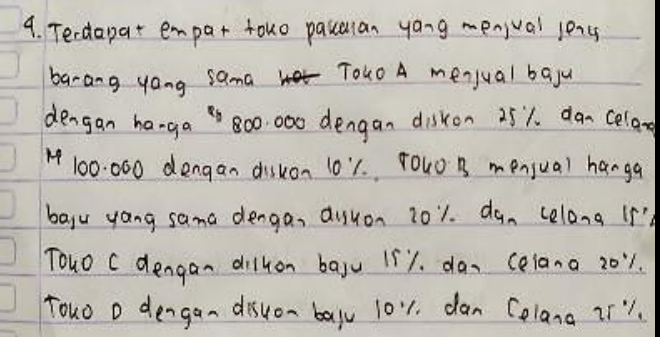

Gambar 4. Respon Siswa terhadap Soal Nomor 4.

\section{3)Transformation Error}

Selanjutnya respon salah satu siswa dalam menjawab soal nomor 2 (lihat gambar 3). Gambar tersebut menjelaskan bahwasannya siswa tidak mampu membangun kerangka berfikir dalam menyusun model matematis dari informasi yang didapatkan. Siswa menjawab soal tidak sesuai dengan model matematika yang seharusnya, sehingga jawaban siswa kurang tepat.

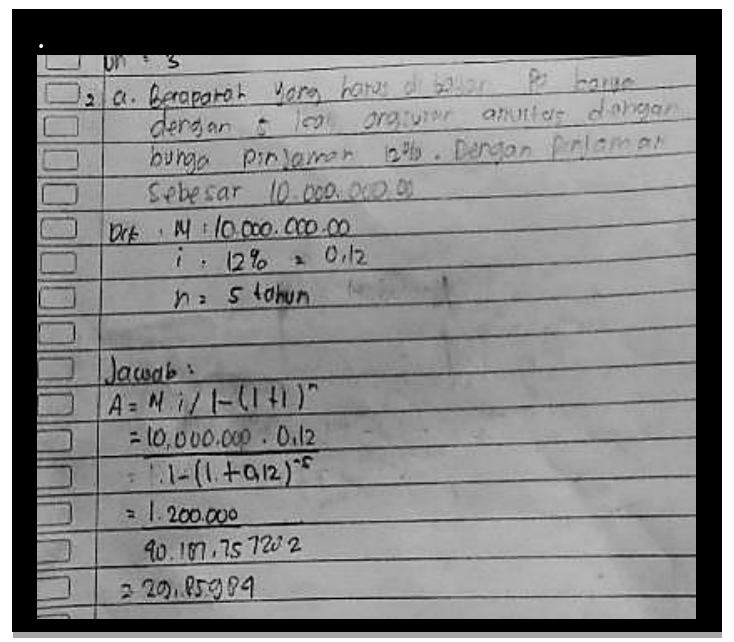

Gambar 5. Respon Siswa terhadap Soal Nomor 2.

Selain itu, penjelasan jawaban siswa pada soal nomor 5 di gambar 4 menunjukkan siswa tidak mengetahui rumus yang akan digunakan untuk menyelesaikan soal. Hal ini sebagaimana jawaban siswa yang menulis jawaban tidak sesuai dengan rumus yang sudah dipelajari.

Sejalan dengan penelitian yang dilakukan oleh Hutajulu, Senjayawati, dan Minarti (2019) mengatakan bahwa siswa belum mampu menganalisa pertanyaan yang ada pada soal, dan berdampak terhadap jawaban siswa yang dibuat seadanya (Nadz \& Haq, 2013; Hutajulu et al., 2019). 


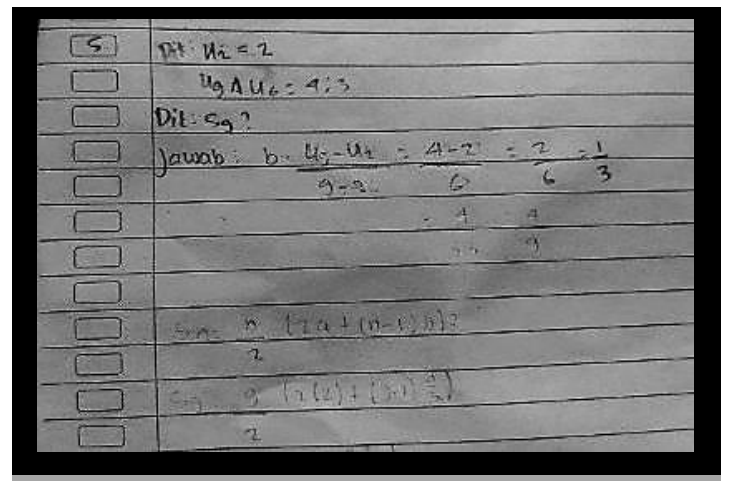

Gambar 6. Respon Siswa terhadap Soal Nomor 5.

\section{4) Process Skill Error}

Selanjutnya jawaban salah satu siswa terhadap soal nomor 2 (lihat gambar 3 ). Terlihat di dalam gambar tersebut siswa tidak mengetahui prosedur serta langkahlangkah yang digunakan untuk menyelesaikan soal dengan tepat. Hal ini sejalan dengan pernyataan Hardiyanti (2016), kesulitan siswa dalam menyelesaikan soal materi barisan dan deret terletak pada penentuan rumus suku ke-n dari suatu barisan aritmatika dan geometri (Hardiyanti, 2016).

$$
\begin{aligned}
& 5 \text { a. } 2 \\
& b=9-6=3 .(4: 3)=3.09 \\
& 2+3.99=8.99 \\
& \text { f. } 99=2=299.5
\end{aligned}
$$

Gambar 7. Respon Siswa terhadap Soal Nomor 2.

\section{5) Encoding Error}

Kemudian jawaban salah satu siswa terhadap soal nomor 2 (lihat gambar 3 ). Terlihat pada gambar tersebut siswa tidak mampu menemukan hasil akhir dari soal berdasarkan prosedur atau langkahlangkah yang telah digunakan.

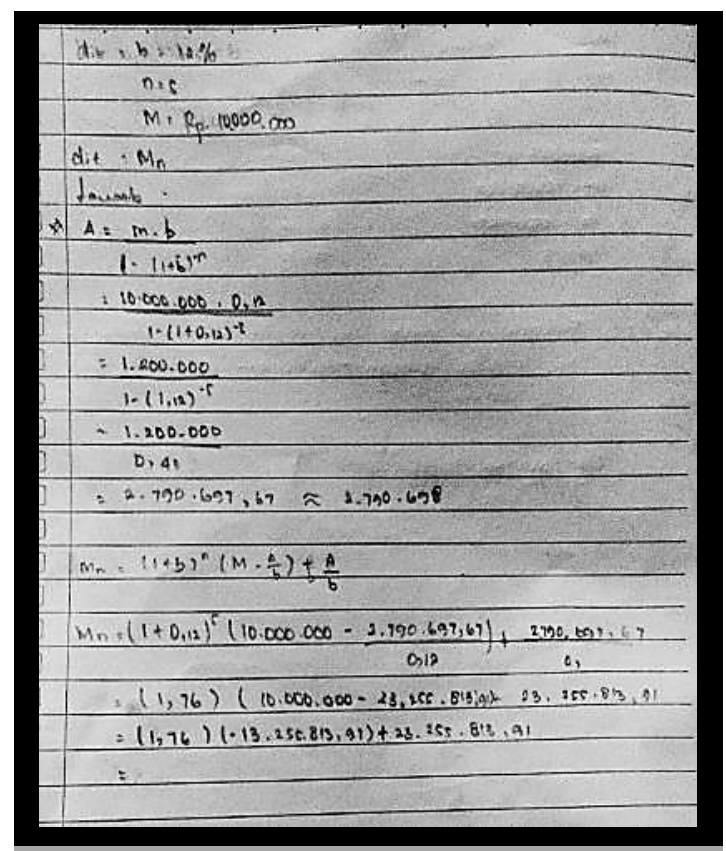

Gambar 8. Respon Siswa terhadap Soal Nomor 2.

Terlihat pada Gambar 7 siswa tidak dapat menunjukan jawaban akhir dari penyelesaian soal dengan benar serta tidak dapat menuliskan jawaban akhir sesuai dengan kesimpulan.

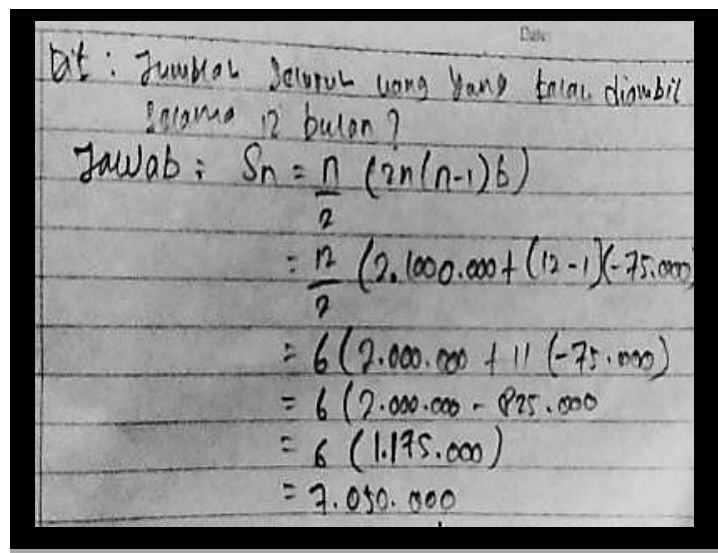

Gambar 9. Respon Siswa terhadap Soal Nomor 3. 
Hal ini sejalan dengan penelitian yang dilakukan Yani, (2019), yang menyatakan bahwa siswa mengalami kesulitan dalam memberikan contoh dari konsep serta mengaitkan berbagai konsep karena tidak memahami konsep dan hanya menghapal rumusnya (Yani et al., 2019).

Berdasarkan data dalam tabel, dalam mengerjakan soal barisan dan deret SMK masih tergolong rendah. Hal ini dapat terlihat jenis kesalahan keterampilan proses merupakan jenis kesalahan terbanyak yang dilakukan oleh subyek walaupun jumlahnya berbeda. Kesalahan keterampilan proses (process skill errors) yang dilakukan subyek dalam mengerjakan soal cenderung memiliki tipe kesalahan yang sama yaitu siswa tidak mampu mengerjakan karena tidak mengetahui prosedur atau langkah-langkah yang akan digunakan untuk menyelesaikan soal dengan tepat. Begitu pula ketika menginjak pada kesalahan selanjutnya yaitu kesalahan memahami masalah (comprehension errors), dimana subyek tidak memahami informasi apa saja yang diketahui dan apa saja yang ditanyakan dalam soal dengan lengkap. Selain process skill errors, subyek juga melakukan kesalahan dalam Comprehension error dan transformation error. Comprehension error yaitu siswa tidak memahami informasi apa saja yang diketahui dalam soal dengan lengkap, dan tidak memahami apa saja yang ditanyakan dalam soal dengan lengkap, sehingga siswa tidak dapat menyusun pertanyaan sekaligus menjawab tentang barisan dan deret dari serangkaian informasi yang diberikan. Sedangkan Transformation error yaitu siswa tidak mengetahui operasi hitung yang akan digunakan untuk menyelesaikan soal serta menyatakan suatu simbol atau diagram atau suatu sajian data lainnya tentang barisan dan deret ke dalam bentuk soal cerita dan menyelesaikannya. Pada soal nomor 5, siswa juga melakukan kesalahan reading error, yaitu siswa tidak mampu membaca atau mengenali simbol dalam soal dan siswa tidak mampu memaknai arti setiap kata, istilah atau simbol dalam soal. Sehingga siswa tidak dapat menyatakan suatu permasalahan barisan dan deret sehari hari ke dalam bentuk model matematika dan menyelesaikannya.

\section{Penutup}

Berdasarkan hasil kajian dalam mengerjakan soal barisan dan deret, jenis kesalahan keterampilan proses merupakan jenis kesalahan terbesar yang dilakukan oleh subyek walaupun jumlahnya berbeda. Kesalahan keterampilan proses (process skill errors) dan transformation error yang dilakukan subyek dalam mengerjakan soal barisan dan deret cenderung memiliki tipe kesalahan yang sama yaitu siswa tidak dapat mengerjakan soal karena tidak mengetahui prosedur atau langkahlangkah yang akan digunakan untuk menyelesaikan soal dengan tepat serta tidak mampu membuat model matematis dari informasi yang didapatkan. 
Pembelajaran yang dilakukan, harus lebih mengutamakan siswa sebagai pusat pembelajaran untuk memahami konsep, sehingga siswa tidak hanya terjebak dalam proses menghafal rumus serta prosedur saja Pendekatan yang diharapkan adalah pendekatan yang membuat siswa dapat menghubungkan materi barisan dan deret dengan kehidupan nyata.

\section{Daftar Pustaka}

Afriansyah, E. A. (2015). Qualitative Became Easier with ATLAS.ti. International Seminar on Mathematics, Science, and Computer Science Education MSCEIS 2015 Universitas Pendidikan Indonesia.

Asy'ari, H. (2015). Analisis Kesalahan Siswa SMP Kelas VIII dalam Menyelesaikan Masalah Soal Cerita Matematika. 151, 10-17.

Bridge, D. M., \& Bridge, D. P. (2017). Fakultas Matematika Dan IImu Pengetahuan Alam UNIVERSITAS BRAWIJAYA (Issue 0251).

Cartledge, G. (2005). Learning disabilities and social skills: Reflections. Learning Disability Quarterly, 28(2), 179-181.

Damayanti, R., \& Afriansyah, E. A. (2018). Perbandingan Kemampuan Representasi Matematis Siswa antara Contextual Teaching and Learning dan Problem Based Learning. JIPM (Jurnal IImiah Pendidikan Matematika), 7(1), 30-39.

Delisda, D., \& Sofyan, D. (2014). Perbandingan Prestasi Belajar Siswa
Antara Yang Mendapatkan Model Pembelajaran Snowball Throwing dan Pembelajaran Konvensional. Mosharafa: Jurnal Pendidikan Matematika, 3(2), 75-84.

Ekayanti, A. (2018). Diagnosis Kesalahan Mahasiswa Dalam Proses Pembuktian Berdasarkan Newmann Error Analysis. Mosharafa: Jurnal Pendidikan Matematika, 6(1), 105-116.

Elbrink, M. (2008). Analyzing and Addressing Common Mathematical Errors in Secondary Education. BS Undergraduate Mathematics Exchange, 5(1), 2-4.

Firmansyah, H. Y., \& Puspitasari, N. (2013). Perbandingan Prestasi Belajar antara Siswa yang Mendapatkan Pembelajaran Matematika Berbasis Karakter dengan Konvensional. Mosharafa: Jurnal Pendidikan Matematika, 2(1), 13-22.

Hardiyanti, A. (2016). Analisis Kesulitan siswa dalam menyelesaikan soal matematika pada materi barisan dan deret. Konferensi Nasional Penelitian Matematika Dan Pembelajarannya (KNPMP I), 2(2), 78-88.

Hidayatilah, L. N., \& Rahadi, M. (2013). Perbedaan Kemampuan Pemecahan Masalah Matematis Siswa yang Mendapatkan Model Pembelajaran Kooperatif Tipe Two Stay Two Stray dengan yang Mendapatkan Model Pembelajaran Numbered Head Together. Mosharafa: Jurnal 
Pendidikan Matematika, 2(3), 155168.

Hutajulu, M., Senjayawati, E., \& Minarti, E. D. (2019). Analisis Kesalahan Siswa SMK Dalam Menyelesaikan Soal Kecakapan Matematis Pada Materi Bangun Ruang. Mosharafa: Jurnal Pendidikan Matematika, 8(3), 365376.

Lestari, N., \& Madio, S. S. (2013). Perbedaan Prestasi Belajar

Matematika Siswa antara yang Mendapatkan Model Pembelajaran Kooperatif Tipe Jigsaw dan Kontekstual. Mosharafa: Jurnal Pendidikan Matematika, 2(3), 169178.

Lexy J. \& Moleong, D. M. A. (2019). Metodologi Penelitian Kualitatif (Edisi Revisi). PT. Remaja Rosda Karya. Mayasari, Y., \& Afriansyah, E. A. (2016). Kemampuan Koneksi Matematis Siswa melalui Model Pembelajaran Berbasis Masalah. Jurnal Riset Pendidikan, 2(1), 27-44.

Nadz, T. F., \& Haq, C. N. (2013). Perbandingan Peningkatan

Kemampuan Penalaran Matematis Siswa yang Memperoleh Pembelajaran melalui Metode Problem Based Instruction (Pbi) dengan Metode Konvensional. Mosharafa: Jurnal Pendidikan Matematika, 2(3), 191-202.

National Council of Teachers of Mathematics. (2000). Principles and
Standards for School Mathematics. School Science and Mathematics.

Putranti, S. D., \& Prahmana, R. C. I. (2018). Kemampuan Siswa Dalam Menyelesaikan Soal Matematika Berbasis Masalah. JNPM (Jurnal Nasional Pendidikan Matematika), 2(1), 86

Rahmawati, C., \& Zanthy, L. S. (2019). Analisis Kemamampuan Komunikasi Siswa Menengah Terhadap Resiliensi Matematis. JPMI (Jurnal Pembelajaran Matematika Inovatif), 2(3), 147

Riccomini, P. J. (2005). Identification and remediation of systematic error patterns in subtraction. Learning Disability Quarterly.

Ridia, N. S., \& Afriansyah, E. A. (2019). Perbandingan Kemampuan Pemahaman Matematis Siswa melalui Auditory Intellectualy Repetition dan Student Teams Achievement Division. Mosharafa: Jurnal Pendidikan Matematika, 8(3), 515-526.

Rusman. (2012). Model-model Pembelajaran Mengembangkan Profesionalisme Guru. Jakarta: Rajawali Pers.

Sartika, G. P., \& Puspitasari, N. (2013). Perbedaan Kemampuan Komunikasi Matematik siswa antara yang Mendapatkan Model Pembelajaran Student Teams Achievement Divisions dengan Model Pembelajaran guided Note Taking. Mosharafa: Jurnal Pendidikan Matematika, 2(2), 87-98. 
Sunardiningsih, G. W., Hariyani, S., \& Fayeldi, T. (2019). Analisis Kesalahan Siswa Dalam Menyelesaikan Soal Matematika Berdasarkan Analisis Newman. Jurnal Terapan Sains \& Teknologi (RAINSTEK), 1(2), 41-45.

Sunyono, Y., L. ., \& Ibrahim, M. (2015). The Online Journal of New Horizons in Education. The Online Journal of New Horizons in Education, 5(2), 30-45.

Sutisna, E. N., \& Nanang. (2013). Pengaruh Model Pembelajaran Kooperatif dengan Pendekatan Number Head Together (Nht) terhadap Kemampuan Komunikasi Matematika Siswa. Mosharafa: Jurnal Pendidikan Matematika, 2(2), 77-86.

Tarigan, D. E. (2012). Analisis Kemampuan Pemecahan Masalah Matematika Berdasarkan Langkah-Langkah Polya Pada Materi Sistem Persamaan Linear Dua Variabel Bagi Siswa Kelas VIII SMP Negeri 9 Surakarta Ditinjau Dari Kemampuan Penalaran Siswa. Universitas Sebelas Maret.

Widiawati, N., \& Sofyan, D. (2013). Perbandingan Prestasi Belajar Matematika Siswa antara yang Mendapatkan Metode Kumon dan Metode Konvensional. Mosharafa: Jurnal Pendidikan Matematika, 2(2), 99-110.

Widyatari, R. (2017). Analisis Kesalahan Siswa Dalam Menyelesaikan Soal Barisan Dan Deret Ditinjau Dari Komunikasi Matematika. Skripsi.
Yani, C. F., Maimunah, M., Roza, Y., Murni, A., \& Daim, Z. (2019). Analisis Kemampuan Pemahaman Matematis Siswa pada Materi Bangun Ruang Sisi Lengkung. Mosharafa: Jurnal Pendidikan Matematika, 8(2), 203214.

Yulianingsih, A., \& Dwinata, A. (n.d.). Analisis Kesalahan Konsep Pecahan pada Siswa Kelas VII A SMP Negeri 13 Satu Atap Tanjungpinang. Mosharafa: Jurnal Pendidikan Matematika, 7(2), 199-206.

\section{Riwayat Hidup PenUlis}

\section{Asri Septiahani}

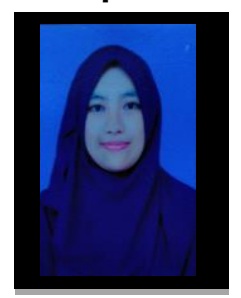

Lahir di Bandung, 6 September 1995. Mahasiswa IKIP Siliwangi Program Studi Pendidikan Matematika.

\section{Melisari}

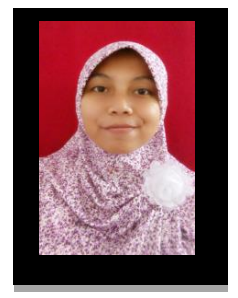
Lahir di Bandung, 26 Agustus 1996. Mahasiswa IKIP Siliwangi Program Studi Pendidikan Matematika.

\section{Dr. Luvy Sylviana Zanthy, S.Pd., M.Pd.}

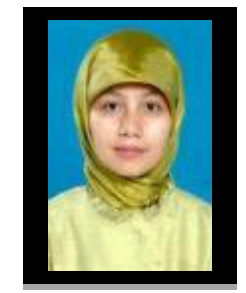

Lahir di Jakarta, 23 November 1977. Staf pengajar di IKIP Siliwangi. Studi S1 Ilmu Tanah di Universitas Padjadjaran, Bandung, lulus tahun 1999; S2 Pendidikan Matematika di Universitas Pendidikan Indonesia, Bandung, lulus tahun 2011; S3 Pendidikan Matematika di Universitas Pendidikan Indonesia, Bandung, lulus tahun 2020. 